\title{
AN EXAMINATION OF THE INDIANA SUPREME COURT DOCKET, DISPOSITIONS, AND VOTING IN 2014*
}

\author{
MARK J. CRANDLEY** \\ JEFFREY M. PEABODY ${ }^{* * *}$
}

Loretta Rush became Indiana's 108th Chief Justice when she was sworn in on November 7, 2014. She assumed the mantle from Justice Brent Dickson, whose capable stewardship in that post ran from May 2012 to August 2014. Justice Dickson remains on the Court, and the change in Chief Justice did not open any new seats. However, the turning point marked by the dawn of the Rush Court in 2014 offers an opportunity to glimpse the future while celebrating the past.

First, the Court retained its hallmark ability to reach consensus in 2014. While consensus has been a cornerstone of the Court's approach to jurisprudence for years, the justices showed remarkable agreement in 2014. The Court reached unanimous results in 88 of its 100 cases. Conversely, the Court split 3-2 in only three cases in 2014. Even examining the voting records of the individual justices reveals the Court's ability to build consensus. Overall, no two justices were aligned in less than $89 \%$ of all cases, and five different pairs of justices agreed in $95 \%$ or more of all cases. Justice Massa agreed with two other justices (Chief Justice Rush and Justice Dickson) in every civil case the Court handed down in 2014. Another indication of the level of consensus on the Court is the scarcity of written dissents. The justices authored only 10 dissenting opinions in 2014. Even rarer were separate concurrences, as the justices wrote only two separate concurrences in all of 2014.

This ability to build consensus produces tangible benefits to Indiana practitioners and citizens. By speaking in one voice, the Court provides clarity and precision as to what the law is. Unanimous opinions tend to minimize dicta and overreaching, as writing justices are cabined by their need to draft opinions that their peers can join. As United States Chief Justice John Roberts-long a proponent of judicial consensus-building - has explained: "Division should not be artificially suppressed, but the rule of law benefits from a broader agreement. The broader the agreement among the justices, the more likely it is a decision on

* The Tables presented in this Article are patterned after the annual statistics of the United States Supreme Court published in the Harvard Law Review. An explanation of the origin of these Tables can be found at Louis Henkin, The Supreme Court, 1967 Term, 82 HARV. L. REV. 63, 301 (1968). The Harvard Law Review granted permission for the use of these Tables by the Indiana Law Review this year; however, permission for any further reproduction of these Tables must be obtained from the Harvard Law Review.

We thank Barnes \& Thornburg LLP for its gracious willingness to devote the time, energy, and resources of its law firm to allow a project such as this to be accomplished. We also thank P. Jason Stephenson, Vice President, General Counsel Vectren Utility Holdings, Inc., for his time and effort shepherding this project over the last several years. As is appropriate, credit for the idea for this project goes to former Chief Justice Shepard.

** Partner, Barnes \& Thornburg LLP, 2005-present; B.A., 1995, Indiana University; J.D., 2000, Indiana University - Maurer School of Law.

*** Associate, Barnes \& Thornburg LLP, 2008-present; B.A., 2003, University of California, Davis; J.D., 2008, Indiana University - Maurer School of Law. 
the narrowest possible grounds."

Conversely, the paucity of dissenting opinions highlights the dissents that are published. As Justice Felix Frankfurter once explained, "[t]he scope of a Supreme Court decision is not infrequently revealed by the candor of dissent." Focused dissents can therefore illuminate core distinctions among the justices, as they illustrate crucial areas where the justices are willing to take the uncommon step of deviating from the rest of the Court.

Second, the Court's docket remains as robust as it has in previous years. The Court handed down 100 opinions in 2014. This was an increase from the 74 in 2013. Over the past five years, the Court has averaged 94.2 opinions per year. The Court's work in 2014 gives no reason to believe that number will change. Indeed, the Court granted 89 new transfer cases in 2014, more than in 2013 and 2012.

Third, the Court's work remains split relatively evenly between civil and criminal cases. In 2014, 58\% of its cases arose in civil cases after the grant of transfer. The percentage of the Court's cases arose in the civil context in 60 civil cases in 2012, while the Court's caseload was almost evenly split in 2013.

Only the coming years (and even decades) can give us a complete picture of the Rush Court. But 2014 serves as an early sign that many of the celebrated characteristics of the Court on which practitioners rely have remained unchanged.

Table A. The Court issued exactly 100 opinions in 2014, up from the 74 opinions issued in 2013 and more in line with the 103 opinions handed down in 2012. For the past five years, the Court has averaged 94.2 opinions per year, a number surely affected by the anomalous year in 2013 when the Court was experiencing rapid changes. The Court again handed down more civil cases than criminal cases, as $58 \%$ of the opinions came in civil cases. The Court has handed down more civil than criminal cases in every year since 2007. For the second year in a row, Justice David authored the most opinions with a total of 21 . He has handed down either the most or the second most opinions every year after 2011. Justice Rucker remains an outspoken voice in dissent, as he authored the most dissenting opinions in 2014. Justice Rucker authored dissents in five cases, which was half of the 10 separate dissenting opinions in 2014. He has either authored the most dissents or tied for the most dissents every year since 2010 .

Table B-1. The Court exhibited a remarkable amount of consensus in civil cases, with Justice Massa agreeing with Chief Justice Rush and Justice Dickson in every civil case the Court handed down in 2014. No justices were aligned with their colleagues less than $90 \%$ of the time in civil cases. The least amount of alignment was between Justices Rucker and David, who agreed in $91 \%$ of civil

1. Associated Press, Chief Justice Says His Goal Is More Consensus on Court, N.Y. TIMES (May 22, 2006), www.nytimes.com/2006/05/22/Washington/22jusitce.html?_r=0, archived at http://perma.cc/W4ZM-7GVF.

2. Felix Frankfurter, The Commerce Clause Under Marshall, Taney and Waite, 106 (1937). 
cases. At no prior point in the past decade have all five justices agreed with each of their colleagues in at least $90 \%$ of civil cases. Although the Shepard-era court was known for its ability to form consensus, the current Court outpaces it in the level of agreement among the justices. For instance, in 2012 - the last year that Chief Justice Shepard and Justice Sullivan were on the Court - the least aligned justices agreed in $57 \%$ of cases and the second least amount of alignment was $64 \%$.

Table B-2. As was the case in 2013, the Court continues to show less alignment in criminal cases. The least aligned judges were Justices Massa and Rucker, who agreed in $83 \%$ of criminal cases. Justice Massa was in the lowest pairing in 2013 as well, as he agreed with Justice Dickson in $83 \%$ of criminal cases that year. The highest alignment was between Justices Rush and David, who agreed in $98 \%$ of criminal cases in 2014. That pair was the second most aligned in criminal cases for 2013 , agreeing in $94 \%$ of the cases that year.

Table B-3. As in 2013, the Court continues to show general alignment across the five justices when looking at all cases. For the second year in a row, no two justices agreed in less than $89 \%$ of cases. In 2014, Justices Massa and Rucker agreed in $89 \%$ of cases, while several pairs of justices shared that amount of alignment in 2013. Every other pairing was over 90\% aligned in both 2013 and 2014. Chief Justice Rush remains a cornerstone of consensus building, as she shared the highest alignment on the Court in all cases. She agreed with both Justices Massa and David in $97 \%$ of all cases. In fact, in her two full years on the bench, Chief Justice Rush has never agreed with any one of her colleagues in less than $91 \%$ of all cases. Justice Rucker was the only justice not to align with at least one of his colleagues in $94 \%$ or more of all cases.

Table C. Continuing the trend from 2013, the percentage of unanimous opinions climbed to $88 \%$ in 2014, up from $84 \%$ in 2013 and well above the percentage of unanimous opinions in $2012(64 \%)$ and 2011 (64.8\%). Of the twelve separate opinions in 2014, only two were concurrences. As has been the case every year over the past decade, the number of dissents (ten) far exceed concurring opinions (two). In other words, the justices tend not to author separate concurring opinions unless compelled to do so, making outright dissents remain more common than concurrences. Consistent with the reduced alignment in criminal cases, 2014 marked the first year since 2009 in which the number of criminal dissents outnumbered the civil dissents. ${ }^{3}$

Table D. The Court handed down only three split decisions in 2014, its lowest total and percentage (3\%) since its jurisdiction changed in 2001. By comparison, 5 of the 74 cases in 2013 (or $6.8 \%$ ) were split decisions, and 16 of the 103 cases in 2012 (or $15.5 \%$ ) were split decisions. Just six years ago, in 2008, the Court split 3-2 in 23 of its 96 cases (or nearly a quarter of the Court's entire caseload).

3. See Mark J. Crandley et al., An Examination of the Indiana Supreme Court Docket, Dispositions and Voting in 2009, 43 IND. L. REV. 541, 542 (2010). 
Chief Justice Rush was in the majority for all three of the 2014 split decisions, and Justices Massa and David were in the majority for two of the split decisions.

Table E-1. The number of reversals rose slightly in 2014, as the Court reversed in $58 \%$ of its cases, as compared to $52 \%$ in 2013 and $56 \%$ in 2012 . The reversal rate remained higher in civil cases, as $65 \%$ of all civil cases coming to the Court on transfer were reversed. Continuing a trend, the Court affirmed in $45 \%$ of its criminal cases arising on transfer. This percentage is consistent with the prior three years, where the Court averaged 42.7 affirmances per year in criminal transfer cases. This recent rate of affirmance is a significant departure for years prior to 2010, as the Court affirmed in more than $30 \%$ of criminal transfer cases only once between 2001 and 2010 . In that time it affirmed less than $20 \%$ of the time in two separate years.

Table E-2. The number of petitions to transfer filed in 2014 dropped by about $6.5 \%$ from 2013. This year marked the first time since 2010 that the Court received fewer than 700 petitions to transfer. The percentage of petitions that the Court granted rose substantially from 2013 , with $12 \%$ of all petitions being granted, as compared to $9.8 \%$ in 2013 . The Court granted only $9 \%$ of petitions in criminal cases while granting $15 \%$ in civil cases and $20 \%$ in juvenile cases.

Table F. The Court's cases continue to cover a broad scope of topics, including 21 different substantive areas of law in 2014. In particular, the Court heard several more cases involving administrative and tax law than in 2013. Negligence and personal injury cases also rose in 2014, with the Court handing down seven such opinions in 2014, as compared to only two in 2013. On the flip side, the Court handed down fewer opinions dealing with divorce, child support and Indiana constitutional law. 
TABLE A

OPINIONS $^{\mathrm{a}}$

\begin{tabular}{lccccccccc}
\hline \hline & \multicolumn{2}{c}{ OPINIONS OF COURT } & \multicolumn{2}{c}{ CONCURRENCES $^{\mathrm{c}}$} & \multicolumn{3}{c}{ DISSENTS $^{\mathrm{d}}$} \\
& Criminal & Civil & Total & Criminal & Civil & Total & Criminal & Civil & Total \\
\hline Dickson, C.J. & 5 & 13 & 18 & 0 & 0 & 0 & 2 & 0 & 2 \\
David, J. & 12 & 9 & 21 & 0 & 0 & 0 & 1 & 1 & 2 \\
Rucker, J. & 7 & 6 & 13 & 0 & 1 & 1 & 3 & 2 & 5 \\
Massa, J. & 7 & 9 & 16 & 1 & 0 & 1 & 0 & 0 & 0 \\
Rush, J. & 8 & 9 & 17 & 0 & 0 & 0 & 0 & 1 & 1 \\
Per Curiam & 3 & 12 & 15 & & & & & & \\
\hline Total & 42 & 58 & 100 & 1 & 1 & 2 & 6 & 4 & 10 \\
\hline \hline
\end{tabular}

a These are opinions and votes on opinions by each justice and in per curiam in the 2014 term. The Indiana Supreme Court is unique because it is the only supreme court to assign each case to a justice by a consensus method. Cases are distributed by a consensus of the justices in the majority on each case either by volunteering or nominating writers. "The chief justice does not have any . . power to direct or control the assignments other than as a member of the majority." See Melinda Gann Hall, Opinion Assignment Procedures and Conference Practices in State Supreme Courts, 73 JuDICATURE 209, 213 (1990). The order of discussion and voting is started by the most junior member of the court and follows in reverse seniority. See id. at 210 .

b This is only a counting of full opinions written by each justice. Plurality opinions that announce the judgment of the court are counted as opinions of the court. It includes opinions on civil, criminal, and original actions.

c This category includes both written concurrences, joining in written concurrence, and votes to concur in result only.

d This category includes both written dissents and votes to dissent without opinion. Opinions concurring in part and dissenting in part, or opinions concurring in part only and differing on another issue, are counted as dissents. 
TABLE B-1 Voting Alignments for Civil CASES $^{\mathrm{e}}$

\begin{tabular}{|c|c|c|c|c|c|c|}
\hline & & Massa & Dickson & David & Rucker & Rush \\
\hline \multirow{5}{*}{ Massa, J. } & $\mathrm{O}$ & & 58 & 56 & 54 & 57 \\
\hline & $\mathrm{S}$ & & 0 & 0 & 0 & 1 \\
\hline & $\mathrm{D}$ & --- & 58 & 56 & 54 & 58 \\
\hline & $\mathrm{N}$ & & 58 & 57 & 58 & 58 \\
\hline & $\mathrm{P}$ & & $100 \%$ & $98 \%$ & $93 \%$ & $100 \%$ \\
\hline \multirow{5}{*}{$\begin{array}{c}\text { Dickson, } \\
\text { C.J. }\end{array}$} & $\mathrm{O}$ & 58 & & 56 & 54 & 57 \\
\hline & $\mathrm{S}$ & 0 & & 0 & 0 & 0 \\
\hline & $\mathrm{D}$ & 58 & --- & 56 & 54 & 57 \\
\hline & $\mathrm{N}$ & 58 & & 57 & 58 & 58 \\
\hline & $\mathrm{P}$ & $100 \%$ & & $98 \%$ & $93 \%$ & $98 \%$ \\
\hline \multirow{5}{*}{ David, J. } & $\mathrm{O}$ & 56 & 56 & & 52 & 55 \\
\hline & $\mathrm{S}$ & 0 & 0 & & 0 & 0 \\
\hline & $\mathrm{D}$ & 56 & 56 & --- & 52 & 55 \\
\hline & $\mathrm{N}$ & 57 & 57 & & 57 & 57 \\
\hline & $\mathrm{P}$ & $98 \%$ & $98 \%$ & & $91 \%$ & $96 \%$ \\
\hline \multirow{5}{*}{ Rucker, J. } & $\mathrm{O}$ & 54 & 54 & 52 & & 54 \\
\hline & $\mathrm{S}$ & 0 & 0 & 0 & & 1 \\
\hline & $\mathrm{D}$ & 54 & 54 & 52 & --- & 55 \\
\hline & $\mathrm{N}$ & 58 & 58 & 57 & & 58 \\
\hline & $\mathrm{P}$ & $93 \%$ & $93 \%$ & $91 \%$ & & $95 \%$ \\
\hline \multirow{5}{*}{ Rush, J. } & $\mathrm{O}$ & 57 & 57 & 55 & 54 & \\
\hline & $\mathrm{S}$ & 1 & 0 & 0 & 1 & \\
\hline & $\mathrm{D}$ & 58 & 57 & 55 & 55 & --- \\
\hline & $\mathrm{N}$ & 58 & 58 & 57 & 58 & \\
\hline & $\mathrm{P}$ & $100 \%$ & $98 \%$ & $96 \%$ & $95 \%$ & \\
\hline
\end{tabular}

e This Table records the number of times that one justice voted with another in full-opinion decisions, including per curiam, for only civil cases. For example, in the top set of numbers for Justice Massa, 58 is the number of times Justice Massa and Chief Justice Dickson agreed in a full majority opinion in a civil case. Two justices are considered to have agreed whenever they joined the same opinion, as indicated by either the reporter or the explicit statement of a justice in the body of his or her own opinion. The Table does not treat two justices as having agreed if they did not join the same opinion, even if they agreed only in the result of the case or wrote separate opinions revealing little philosophical disagreement.

"O" represents the number of decisions in which the two justices agreed in opinions of the court or opinions announcing the judgment of the court.

"S" represents the number of decisions in which the two justices agreed in separate opinions, including agreements in both concurrences and dissents.

"D" represents the number of decisions in which the two justices agreed in either a majority, dissenting, or concurring opinion.

"N" represents the number of decisions in which both justices participated and thus the number of opportunities for agreement.

"P" represents the percentage of decisions in which one justice agreed with another justice, calculated by dividing "D" by "N." 
TABLE B-2

Voting Alignments for Criminal CASES $^{\mathrm{f}}$

\begin{tabular}{|c|c|c|c|c|c|c|}
\hline & & Massa & Dickson & David & Rucker & Rush \\
\hline \multirow{5}{*}{ Massa, J. } & $\mathrm{O}$ & & 36 & 38 & 35 & 39 \\
\hline & $\mathrm{S}$ & & 1 & 0 & 0 & 0 \\
\hline & D & --- & 37 & 38 & 35 & 39 \\
\hline & $\mathrm{N}$ & & 42 & 42 & 42 & 42 \\
\hline & $\mathrm{P}$ & & $88 \%$ & $90 \%$ & $83 \%$ & $93 \%$ \\
\hline \multirow{5}{*}{$\begin{array}{c}\text { Dickson, } \\
\text { C.J. }\end{array}$} & $\mathrm{O}$ & 36 & & 37 & 36 & 38 \\
\hline & $\mathrm{S}$ & 1 & & 0 & 2 & 0 \\
\hline & D & 37 & --- & 37 & 38 & 38 \\
\hline & $\mathrm{N}$ & 42 & & 42 & 42 & 42 \\
\hline & $\mathrm{P}$ & $88 \%$ & & $88 \%$ & $90 \%$ & $90 \%$ \\
\hline \multirow{5}{*}{ David, J. } & $\mathrm{O}$ & 38 & 37 & & 38 & 41 \\
\hline & $\mathrm{S}$ & 0 & 0 & & 1 & 0 \\
\hline & D & 38 & 37 & --- & 39 & 41 \\
\hline & $\mathrm{N}$ & 42 & 42 & & 42 & 42 \\
\hline & $\mathrm{P}$ & $90 \%$ & $88 \%$ & & $93 \%$ & $98 \%$ \\
\hline \multirow{5}{*}{ Rucker, J. } & $\mathrm{O}$ & 35 & 36 & 38 & & 38 \\
\hline & $\mathrm{S}$ & 0 & 2 & 1 & & 0 \\
\hline & D & 35 & 38 & 39 & --- & 38 \\
\hline & $\mathrm{N}$ & 42 & 42 & 42 & & 42 \\
\hline & $\mathrm{P}$ & $83 \%$ & $90 \%$ & $93 \%$ & & $90 \%$ \\
\hline \multirow{5}{*}{ Rush, J. } & $\mathrm{O}$ & 39 & 38 & 41 & 38 & \\
\hline & $\mathrm{S}$ & 0 & 0 & 0 & 0 & \\
\hline & D & 39 & 38 & 41 & 38 & --- \\
\hline & $\mathrm{N}$ & 42 & 42 & 42 & 42 & \\
\hline & $\mathrm{P}$ & $93 \%$ & $90 \%$ & $98 \%$ & $90 \%$ & \\
\hline
\end{tabular}

f This Table records the number of times that one justice voted with another in full-opinion decisions, including per curiam, for only criminal cases. For example, in the top set of numbers for Justice Massa, 36is the number of times former Justice Massa and Chief Justice Dickson agreed in a full majority opinion in a criminal case. Two justices are considered to have agreed whenever they joined the same opinion, as indicated by either the reporter or the explicit statement of a justice in the body of his or her own opinion. The Table does not treat two justices as having agreed if they did not join the same opinion, even if they agreed only in the result of the case or wrote separate opinions revealing little philosophical disagreement.

"O" represents the number of decisions in which the two justices agreed in opinions of the court or opinions announcing the judgment of the court.

"S" represents the number of decisions in which the two justices agreed in separate opinions, including agreements in both concurrences and dissents.

"D" represents the number of decisions in which the two justices agreed in either a majority, dissenting, or concurring opinion.

"N" represents the number of decisions in which both justices participated and thus the number of opportunities for agreement.

"P" represents the percentage of decisions in which one justice agreed with another justice, calculated by dividing "D" by "N." 
TABLE B-3

Voting AlignMents for All CASEs ${ }^{g}$

\begin{tabular}{|c|c|c|c|c|c|c|}
\hline & & Massa & Dickson & David & Rucker & Rush \\
\hline \multirow{5}{*}{ Massa, J. } & $\mathrm{O}$ & & 94 & 94 & 89 & 96 \\
\hline & $\mathrm{S}$ & & 1 & 0 & 0 & 1 \\
\hline & D & --- & 95 & 94 & 89 & 97 \\
\hline & $\mathrm{N}$ & & 100 & 99 & 100 & 100 \\
\hline & $\mathrm{P}$ & & $95 \%$ & $95 \%$ & $89 \%$ & $97 \%$ \\
\hline \multirow{5}{*}{$\begin{array}{c}\text { Dickson, } \\
\text { C.J. }\end{array}$} & $\mathrm{O}$ & 94 & & 93 & 90 & 95 \\
\hline & $\mathrm{S}$ & 1 & & 0 & 2 & 0 \\
\hline & D & 95 & --- & 93 & 92 & 95 \\
\hline & $\mathrm{N}$ & 100 & & 99 & 100 & 100 \\
\hline & $\mathrm{P}$ & $95 \%$ & & $94 \%$ & $92 \%$ & $95 \%$ \\
\hline \multirow{5}{*}{ David, J. } & $\mathrm{O}$ & 94 & 93 & & 90 & 96 \\
\hline & $\mathrm{S}$ & 0 & 0 & & 1 & 0 \\
\hline & D & 94 & 93 & --- & 91 & 96 \\
\hline & $\mathrm{N}$ & 99 & 99 & & 99 & 99 \\
\hline & $\mathrm{P}$ & $95 \%$ & $94 \%$ & & $92 \%$ & $97 \%$ \\
\hline \multirow{5}{*}{ Rucker, J. } & $\mathrm{O}$ & 89 & 90 & 90 & & 92 \\
\hline & $\mathrm{S}$ & 0 & 2 & 1 & & 1 \\
\hline & D & 89 & 92 & 91 & --- & 93 \\
\hline & $\mathrm{N}$ & 100 & 100 & 99 & & 100 \\
\hline & $\mathrm{P}$ & $89 \%$ & $92 \%$ & $92 \%$ & & $93 \%$ \\
\hline \multirow{5}{*}{ Rush, J. } & $\mathrm{O}$ & 96 & 95 & 96 & 92 & \\
\hline & $\mathrm{S}$ & 1 & 0 & 0 & 1 & \\
\hline & D & 97 & 95 & 96 & 93 & --- \\
\hline & $\mathrm{N}$ & 100 & 100 & 99 & 100 & \\
\hline & $\mathrm{P}$ & $97 \%$ & $95 \%$ & $97 \%$ & $93 \%$ & \\
\hline
\end{tabular}

$\mathrm{g}$ This Table records the number of times that one justice voted with another in full-opinion decisions, including per curiam, for all cases. For example, in the top set of numbers for former Justice Massa, 94 is the total number of times former Justice Massa and Chief Justice Dickson agreed in all full majority opinions written by the court in 2014. Two justices are considered to have agreed whenever they joined the same opinion, as indicated by either the reporter or the explicit statement of a justice in the body of his or her own opinion. The Table does not treat two justices as having agreed if they did not join the same opinion, even if they agreed only in the result of the case or wrote separate opinions revealing little philosophical disagreement.

"O" represents the number of decisions in which the two justices agreed in opinions of the court or opinions announcing the judgment of the court.

"S" represents the number of decisions in which the two justices agreed in separate opinions, including agreements in both concurrences and dissents.

" $D$ " represents the number of decisions in which the two justices agreed in either a majority, dissenting, or concurring opinion.

"N" represents the number of decisions in which both justices participated and thus the number of opportunities for agreement.

"P" represents the percentage of decisions in which one justice agreed with another justice, calculated by dividing "D" by "N." 
TABLE C

UNANIMITY

(NOT INCLUDING JUDICIAL OR ATTORNEY DISCIPLINE CASES) ${ }^{\text {h }}$

\begin{tabular}{|c|c|c|c|c|c|c|c|c|c|}
\hline \multicolumn{3}{|c|}{ Unanimous ${ }^{\mathrm{i}}$} & \multicolumn{3}{|c|}{$\begin{array}{c}\text { Unanimous } \\
\text { with Concurrence }\end{array}$} & \multicolumn{3}{|c|}{$\begin{array}{c}\text { Opinions } \\
\text { with Dissent }\end{array}$} & \multirow[t]{2}{*}{ Total } \\
\hline Criminal & Civil & Total & Criminal & Civil & Total & Criminal & Civil & Total & \\
\hline 35 & 53 & 88 & 1 & 1 & 2 & 6 & 4 & 10 & 100 \\
\hline
\end{tabular}

h This Table tracks the number and percent of unanimous opinions among all opinions written. If, for example, only four justices participated and all concurred, it is still considered unanimous. It also tracks the percentage of overall opinions with concurrence and overall opinions with dissent.

i A decision is considered unanimous only when all justices participating in the case voted to concur in the court's opinion, as well as its judgment. When one or more justices concurred in the result, but not in the opinion, the case is not considered unanimous.

j A decision is listed in this column if one or more justices concurred in the result, but not in the opinion of the court or wrote a concurrence, and there were no dissents. 
TABLE D

SPLIT DeCisions ${ }^{k}$

\begin{tabular}{lc}
\hline \hline Justices Constituting the Majority & Number of Opinions $^{\mathbf{1}}$ \\
\hline 1. Dickson, C.J., Massa, J., Rush, J. & 1 \\
2. Massa, J., David, J., Rush, J. & 1 \\
3. David, J., Rucker, J., Rush, J. & 1 \\
\hline Total $^{\mathrm{m}}$ & 3 \\
\hline
\end{tabular}

k This Table concerns only decisions rendered by full opinion. An opinion is counted as a split decision if two or more justices voted to decide the case in a manner different from that of the majority of the court.

1 This column lists the number of times each group of justices constituted the majority in a split decision.

m The 2014 term's split decisions were:

1. Dickson, C.J., Massa, J., Rush, J: Thang v. State, 10 N.E.3d 1256 (Ind. 2014) (Dickson, C.J.).

2. Massa, J., David, J., Rush, J.: Erkins v. State, 13 N.E.3d 400 (Ind. 2014) (David, J.).

3. David, J., Rucker, J., Rush, J.: Parks v. State, 22 N.E.3d 552 (Ind. 2014) (David, J.). 
TABLE E-1

DisPoSITION OF CASES REVIEWED BY TRANSFER AND DIRECT APPEALS ${ }^{n}$

\begin{tabular}{lccc}
\hline \hline & Reversed or Vacated & Affirmed & Total \\
\hline Civil Appeals Accepted for Transfer & $31(65 \%)$ & $17(35 \%)$ & 48 \\
Direct Civil Appeals & $8(80 \%)$ & $2(20 \%)$ & 10 \\
Criminal Appeals Accepted for Transfer & $19(48 \%)$ & $21(52 \%)$ & 40 \\
Direct Criminal Appeals & $0(0 \%)$ & $2(100 \%)$ & 2 \\
\hline Total & $58(58 \%)$ & $42(42 \%)$ & 100 \\
\hline \hline
\end{tabular}

n Direct criminal appeals are cases in which the trial court imposed a death sentence. See IND. CONST. art. VII, $\S 4$. Thus, direct criminal appeals are those directly from the trial court. A civil appeal may also be direct from the trial court. See IND. APP. R. 56, R. 63; see also Rules of Procedure for Original Actions. All other Indiana Supreme Court opinions are accepted for transfer from the Indiana Court of Appeals. See IND. APP. R. 57.

o Generally, the Indiana Supreme Court uses the term "vacate" when it is reviewing a court of appeals opinion, and the term "reverse" when the court overrules a trial court decision. A point to consider in reviewing this Table is that the court technically "vacates" every court of appeals opinion that is accepted for transfer, but may only disagree with a small portion of the reasoning and still agree with the result. See IND. APP. R. 58(A). As a practical matter, "reverse" or "vacate" simply represents any action by the court that does not affirm the trial court or court of appeals's opinion. 
TABLE E-2

Disposition of Petitions to Transfer

TO SUPREME COURT IN 2014

\begin{tabular}{lccrr}
\hline \hline & Denied or Dismissed & Granted & Total \\
\hline Petitions to Transfer & & & & \\
Civil $^{q}$ & $179(85 \%)$ & 32 & $(15 \%)$ & 211 \\
Criminal $^{\mathrm{r}}$ & $450(91 \%)$ & 45 & $(9 \%)$ & 495 \\
Juvenile $^{\mathrm{s}}$ & $47(80 \%)$ & 12 & $(20 \%)$ & 59 \\
\hline Total & $676(88 \%)$ & 89 & $(12 \%)$ & 765 \\
\hline \hline
\end{tabular}

p This Table analyzes the disposition of petitions to transfer by the court. See IND. APP. R. 58(A).

q This also includes petitions to transfer in tax cases and workers' compensation cases.

This also includes petitions to transfer in post-conviction relief cases.

s This also includes guardianship and adoption cases. 
TABLE F

SubJect AREAS OF Selected Dispositions

WITH FULL OPINIONS ${ }^{t}$

\begin{tabular}{|c|c|}
\hline Original Actions & Number \\
\hline - Certified Questions & 0 \\
\hline - Writs of Mandamus or Prohibition & 0 \\
\hline - Attorney Discipline & $3^{u}$ \\
\hline - Judicial Discipline & $1^{\mathrm{v}}$ \\
\hline \multicolumn{2}{|l|}{ Criminal } \\
\hline - Death Penalty & $2^{w}$ \\
\hline - Fourth Amendment or Search and Seizure & $6^{\mathrm{x}}$ \\
\hline - Writ of Habeas Corpus & 0 \\
\hline Emergency Appeals to the Supreme Court & 0 \\
\hline Trusts, Estates, or Probate & $1^{\mathrm{y}}$ \\
\hline Real Estate or Real Property & $3^{\mathrm{z}}$ \\
\hline Personal Property & 0 \\
\hline Landlord-Tenant & 0 \\
\hline Divorce or Child Support & $3^{\text {aa }}$ \\
\hline Children in Need of Services (CHINS) & $4^{\mathrm{bb}}$ \\
\hline Paternity & 0 \\
\hline Product Liability or Strict Liability & 0 \\
\hline Negligence or Personal Injury & $7^{\mathrm{cc}}$ \\
\hline Invasion of Privacy & 0 \\
\hline Medical Malpractice & $3^{\mathrm{dd}}$ \\
\hline Indiana Tort Claims Act & $2^{\mathrm{ee}}$ \\
\hline Statute of Limitations or Statute of Repose & $4^{\mathrm{ff}}$ \\
\hline Tax, Department of State Revenue, or State Board of Tax Commissioners & $3^{\mathrm{gg}}$ \\
\hline Contracts & $2^{\text {hh }}$ \\
\hline Corporate Law or the Indiana Business Corporation Law & $1^{\mathrm{ii}}$ \\
\hline Uniform Commercial Code & 0 \\
\hline Banking Law & 0 \\
\hline Employment Law & $2^{\mathrm{jj}}$ \\
\hline Insurance Law & $4^{\mathrm{kk}}$ \\
\hline Environmental Law & $1^{11}$ \\
\hline Consumer Law & 0 \\
\hline Worker's Compensation & 0 \\
\hline Arbitration & 0 \\
\hline Administrative Law & $5^{\mathrm{mm}}$ \\
\hline First Amendment, Open Door Law, or Public Records Law & $2^{\mathrm{nn}}$ \\
\hline Full Faith and Credit & 0 \\
\hline Eleventh Amendment & 0 \\
\hline Civil Rights & $1^{\text {oo }}$ \\
\hline Indiana Constitution & $2^{\mathrm{pp}}$ \\
\hline
\end{tabular}

This Table is designed to provide a general idea of the specific subject areas upon which the court ruled or discussed and how many times it did so in 2014. It is also a quick-reference guide to court rulings for practitioners in specific areas of the law. The numbers corresponding to the areas of law reflect the number of cases in which the court substantively discussed legal issues about these subject areas. Also, any attorney discipline case resolved by order (as opposed to an opinion) was not considered in preparing this Table. 
u $\quad$ In re Atkins, 16 N.E.3d 950 (Ind. 2014); In re Stern, 11 N.E.3d 917 (Ind. 2014).; In re Brejensky, 11 N.E.3d 914 (Ind. 2014).

v $\quad$ In re Weber, 21 N.E.3d 92 (Ind. 2014).

w Knapp v. State, 9 N.E.3d 1274 (Ind. 2014); Inman v. State, 4 N.E.3d 190 (Ind. 2014).

x Carpenter v. State, 18 N.E.3d 998 (Ind. 2014); Guilmette v. State, 14 N.E.3d 38 (Ind. 2014); Gaddie v. State, 10 N.E.3d 1249 (Ind. 2014); McIlquham v. State, 10 N.E.3d 506 (Ind. 2014); Robinson v. State, 5 N.E.3d 362 (Ind. 2014); State v. Keck, 4 N.E.3d 1180 (Ind. 2014).

y Old Nat'l Bancorp v. Hanover College, 15 N.E.3d 574 (Ind. 2014).

z Wysocki v. Johnson, 18 N.E.3d 600 (Ind. 2014); Fischer v. Heymann, 12 N.E.3d 867 (Ind. 2014); Am. Cold Storage v. City of Boonville, 2 N.E.3d 3 (Ind. 2014).

aa Rolley v. Rolley, 22 N.E.3d 558 (Ind. 2014); D.M.Y. v. B.Y., 17 N.E.3d 272 (Ind. 2014); Pohl v. Pohl, 15 N.E.3d 1006 (Ind. 2014).

bb K.W. v. Ind. Dep't of Child Servs., 12 N.E.3d 241 (Ind. 2014); In re G.P., 4 N.E.3d 1158 (Ind. 2014); In re E.M., 4 N.E.3d 636 (Ind. 2014); In re S.D., 2 N.E.3d 1283 (Ind. 2014).

cc Camoplast Crocker, LLC v. Schoolcraft, 12 N.E.3d 251 (Ind. 2014); South Shore Baseball, LLC v. DeJesus, 11 N.E.3d 903 (Ind. 2014); Alldredge v. Good Samaritan Home, Inc., 9 N.E.3d 1257 (Ind. 2014); Smith v. Delta Tau Delta, 9 N.E.3d 154 (Ind. 2014); Groce v. Am. Family Mut. Ins. Co., 5 N.E.3d 1154 (Ind. 2014); Hardiman v. Cozmanoff, 4 N.E.3d 1148 (Ind. 2014); Yost v. Wabash College, 3 N.E.3d 509 (Ind. 2014).

dd Ind. Patient's Comp. Fund v. Holcomb, 17 N.E.3d 255 (Ind. 2014); David v. Kleckner, 9 N.E.3d 147 (Ind. 2014); Moryl v. Ransone, 4 N.E.3d 1133 (Ind. 2014).

ee Lyons v. Richmond Cmty. Sch. Corp., 19 N.E.3d 254 (Ind. 2014); Veolia Water Indianapolis, LLC v. Nat'1 Trust Ins. Co., 3 N.E.3d 1 (Ind. 2014).

ff $\quad$ Alldredge, 9 N.E.3d 1257; David v. Kleckner, 9 N.E.3d 147 (Ind. 2014); Groce, 5 N.E.3d 1154; Moryl, 4 N.E.3d 1133.

gg In re Carroll Cnty. 2013 Tax Sale, 21 N.E.3d 832 (Ind. 2014); In re Carroll Cnty. 2012 Tax Sale, 21 N.E.3d 91 (Ind. 2014); Ind. Dep't of State Revenue v. Caterpillar, Inc., 15 N.E.3d 579 (Ind. 2014).

hh Fischer v. Heymann, 12 N.E.3d 867 (Ind. 2014); Alva Elec., Inc. v. Evansville-Vanderburgh Sch. Corp., 7 N.E.3d 263 (Ind. 2014).

ii TP Orthodontics, Inc. v. Kesling, 15 N.E.3d 985 (Ind. 2014).

jj Zoeller v. Sweeney, 19 N.E.3d 749 (Ind. 2014); Andrews v. Mor/Ryde Int'l, Inc., 10 N.E.3d 502 (Ind. 2014).

kk Robinson v. Erie Ins. Exch., 9 N.E.3d 673 (Ind. 2014); Asklar v. Gilb, 9 N.E.3d 165 (Ind. 2014); Groce, 5 N.E.3d 1154; Justice v. Am. Family Mut. Ins. Co., 4 N.E.3d 1171 (Ind. 2014).

$11 \quad$ NRDC v. Poet Biorefining, 15 N.E.3d 555 (Ind. 2014).

mm Teaching Our Posterity Success, Inc. v. Ind. Dep't of Educ., 20 N.E.3d 149 (Ind. 2014); First Am. Title Ins. Co. v. Robertson, 19 N.E.3d 757 (Ind. 2014); Ind. State Ethics Comm'n v. Sanchez, 18 N.E.3d 988 (Ind. 2014); NRDC v. Poet Biorefining, 15 N.E.3d 555 (Ind. 2014); Fayette County Bd. of Comm'rs v. Price, 9 N.E.3d 640 (Ind. 2014).

nn Evansville Courier \& Press v. Vanderburgh County Health Dep't, 17 N.E.3d 922 (Ind. 2014); Brewington v. State, 7 N.E.3d 946 (Ind. 2014).

oo Bond v. State, 9 N.E.3d 134 (Ind. 2014).

pp Zoeller v. Sweeney, 19 N.E.3d 749 (Ind. 2014); Paul Stieler Enters., Inc. v. City of Evansville, 2 N.E.3d 1269 (Ind. 2014). 